\title{
Effects of Christian Faith Sharing Through Social Media: Examining Belief System Changes, Behavioral Changes, and User Preferences
}

\author{
Glen Alan Bowman, Blessing Osueke and Samantha Baires
}

York College, USA. Email: gbowman15@gmail.com

\begin{abstract}
This research examined the effects of Christian faith sharing through social media on the belief systems and behavior of users who encounter those messages. In addition, it explored methods of Christian social media faith sharing to discover if users had consistent preferences for certain methods or found some methods more offensive than others. To explore these topics, a quantitative survey was completed by 79 students, faculty, and staff at a Christian college in the Midwestern United States. From this survey, social media users that encountered Christian faith sharing reported a slight to moderate effect size in their changes of both their belief systems and behavior as a result of that message. Furthermore, they reported appreciating certain methods of social media faith sharing from Christians more than others, with personal stories about how God changed others' lives as most impactful and most preferred to encounter. Finally, they indicated that Christian chain messages on social media and posts that requested likes or retweets were most offensive. These findings demonstrate that Christian faith sharing through social media impacts the beliefs and behavior of those who encounter it and that users strongly prefer some methods that Christians use over others.
\end{abstract}

KEYWORDS: Behavior, belief systems, Christian, faith sharing, offensive, preference, social media

\section{Effects of Christian Faith Sharing Through Social Media:}

\section{Examining Belief System Changes, Behavioral Changes, and User Preferences}

Christians have shared their beliefs with others since their foundation of their religion almost 2,000 years ago, which has often resulted in serious persecution of those believers (Diprose, 2018; Lehtipuu, 2016; Philips, 2015). In most modern Western societies, the severity of persecution has decreased in terms of violence, but various forms of persecution still take place frequently today (Lie, 2017; Van der Walt, 2017). Since recurrent worldwide conflicts between Christians and those who encounter their faith sharing still occurs today, it seems relevant to study the effects of Christians when they share their faith on those who encounter their message.

Recently, Christian faith sharing has expanded to social media, as evident from a study where $20 \%$ of adults in the United States reported that they shared their faith on Facebook in the last week and $46 \%$ encountered someone else share their faith on that platform during that time (Brubaker \& Haigh, 2017). Additionally, social media has become commonplace in modern society, with four out of five people who have access to the Internet using some form of social media (Lim, 2017). Users spend far more time on social media than any other purpose on the Internet and many users spend hours on social networking sites each day (Vidyakala \& Nithyakala, 2016). This explosion of social media use that now incorporates billions of people (Bowman, 2019) can exert a greater influence on younger people who use it more often (Kelly, 2015). Consequently, people have used social media as a tool to affect change in society, even within the context of religious causes (Lee \& Hsieh, 2016; Lim, 2017). In connection with this means of impact, Christians have shifted towards this growing platform of social media for sharing their faith, based largely on their compulsion from the biblical commands towards that goal (Previte, 2017; 2 Corinthians 5:11-20; 2 Timothy 4:12 ). The recent decline of attendance in Western churches (Audette $\&$ Weaver, 2016) has amplified the sense of urgency that many Christians feel to produce greater impact through sharing their faith with others (Van der Walt, 2017).

In addition, Christians often share their faith without understanding their intended audiences' thoughts, desires, and the effectiveness of their techniques (Lie, 2017; Previte, 2017). Accordingly, their faith sharing techniques have produced mixed results, often receiving intense criticism and persecution from others (Lehtipuu, 2016; Philips, 2015). The results have recently seemed less impactful towards behavior in the United States, where most people still believe that the Bible contains the word of God (O’Brien \& Noy, 2015) but often do not participate in various Christian activities such as attending worship services (Voas \& Chaves, 2016). Based on this literature, this study examined if and to what extent social media users perceived effects that Christians' faith sharing through social media has on their belief systems and behavior. It also explored methods of Christian social media faith 
sharing to discover if users had consistent preferences for certain methods or found some methods more offensive than others. This research may engender positive change between Christian faith sharers using social media and those who encounter their faith sharing messages by bringing a greater understanding to those Christians, prompting them to share their faith more wisely and less offensively.

Recent research has described Christian techniques used in sharing their faith through social media (e.g., Efiong, 2015; Lie, 2017; White, Tella, \& Ampofo, 2016). For example, White et al. (2016) took a common approach in the literature toward this topic by simply describing certain pastors' faith sharing techniques using Facebook but without describing the results. Using a more detailed approach, Previte (2017) qualitatively studied Christian adolescents sharing their faith through social media by interviewing those faith sharers and the adults that mentored the adolescents in their faith. Furthermore, Mayhew et al. (2017) quantitatively studied how other college students who do not practice in Christian faith sharing gained an appreciative attitude towards Christian college students who share their faith. Many of these articles have described Christians sharing their faith through social media and Mayhew et al. (2017) even described the perceptions towards the Christian faith sharers themselves, but none of them measure the effectiveness of Christian faith sharing through social media on their intended audience. As Previte (2017) noted, there have not been quantitative studies that measure the perceived effects on those who encounter that faith sharing. In addition, Bosch, Sanz, Abello, Torrents, and Gauxachs (2017) stated the need for a study to examine the people that interacted with popular Catholic faith sharing websites, which including social media sites, to understand the users' perspective. Therefore, the gaps stated by Bosch et al. (2017) and Previte (2017) have described the need to examine the effects that Christian faith sharing through social media has on the recipients' belief systems and behavior.

The belief systems mentioned in this research encompass thoughts, opinions, and a mental acceptance about what is true, which can change based on actions and events in the environment (Bandura, 1963, 1965). Behavior for this study describes an outward action, which could vary from previous actions based on a change in thinking and beliefs (Bandura, 1969; Bandura, Ross, \& Ross, 1963). Based on the theoretical framework of Bandura's social learning theory (Bandura, 1963, 1965, 1969, 1971), the research questions and hypotheses provided in this section guided this quantitative study. The first two research questions and hypotheses appear below followed by a rationale for these hypotheses.

R1: If and to what extent does Christian faith sharing through social media impact social media users' belief systems?
H1: Christian faith sharing through social media impacts social media users' belief systems to a moderate extent.

R2: If and to what extent does Christian faith sharing through social media impact social media users' behavior?

H2: Christian faith sharing through social media social media users' behavior to no significant extent.

The researchers chose the first hypothesis based largely on the influences described in social learning theory and the second hypothesis largely from societal pressures that might hinder behavioral change. Bandura's (1965) research showed that behavior can contradict newly formed belief systems when the environmental pressures push those people in a particular direction. Therefore, the researchers believed that social media users may receive a moderate impact in belief systems from Christian faith sharing through social media (H1), but not significantly change their behavior based on perceived pressure from their peers and others in society to behavior in the same manner (H2).

Three other research questions referred to different types of Christian faith sharing posts through social media and the potential differences in the effects on users' belief systems, behavior, and preferences. The researchers believed that different categories of posts would have differing impacts on belief systems and behavior. In addition, they believed that social media users would have preferences for some types of posts and feel more offended by other types of posts. Therefore, the alternative hypotheses were chosen for research questions 3-5 based on personal observations from the researchers' own social media experiences and past comments from others. These research questions and the corresponding hypotheses appear below.

R3: Do diverse methods of Christian faith sharing through social media differentially impact social media users' belief systems and/or behavior?

H3: Diverse methods of Christian faith sharing through social media impact social media users' belief systems and/or behavior to varying extents.

R4: Do social media users prefer certain methods of Christian faith sharing through social media over others?

H4: Social media users prefer certain methods of Christian faith sharing through social media over others.

R5: Do social media users take more offense from certain methods of Christian faith sharing through social media over others?

H5: Social media users take more offense from certain methods of Christian faith sharing through social media over others. 


\section{Methods}

This research used the theoretical framework of social learning theory developed by Albert Bandura (1963, 1965, 1969, 1971). This theory outlined steps for learning in society, which explains how people first make observations of others' modeled behavior which impacts the environment surrounding people (Knafo, 2016). Changes in these environmental factors that differ from previous social norms can result in observational learning, first through mental coding of the novel information in observers' thoughts and then can alter their consequent behavior (Bandura, 1971; Bandura et al, 1963). This theory has become widely accepted and applied in modern scholarly thought beyond psychological circles (Chen, Wang, \& Hung, 2015) and even used to explain potential influences through social media (Deaton, 2015). This theoretical framework helped to guide formation of the research questions and the corresponding questions used in the quantitative survey. After crafting a survey, the researchers used an expert panel including a psychology professor, a Bible professor, and college students to provide feedback resulting in minor wording changes.

Undergraduate students, staff members, and faculty of a Midwestern Christian college were asked to participate in the study. After a chapel recruitment announcement at the institution where students, faculty, and staff gathered every weekday, all those in attendance had the opportunity to take part in a one-page survey (front and back) that was also made available afterwards at the college's library and cafeteria. The survey posed questions about the effects from encountering Christian faith sharing through social media on users' belief systems and behavior using a Likerttype scale. The first section of the survey asked the questions stated below. The questions were not numbered in the survey, but have been given numbers here for ease of references and understanding in this paper.

1. When you encounter Christians sharing their faith through social media, how often has it affected your belief systems concerning anything connected to your faith?

2. When you encounter Christians sharing their faith through social media, how often has it affected your belief systems in any other areas?

3. When you encounter Christians sharing their faith through social media, how often have you felt pressure to change your beliefs and/or actions?

4. After encountering Christians sharing their faith through social media, how often has it affected your behavior concerning anything connected to your faith?

5. After encountering Christians sharing their faith through social media, how often has it affected your behavior in any other areas?
6. To what degree would you estimate that encountering Christians sharing their faith through social media has affected your belief systems?

7. To what degree would you estimate that encountering Christians sharing their faith through social media has affected your behavior?

8. How frequently do you encounter Christians sharing their faith through social media?

Questions 1-5 had the following options for responding as a Likert-type scale: never, rarely, sometimes, frequently, and all the time, scored on a scale of 1-5 in that order. Questions 6-7 included the following options: not at all, slightly, somewhat, significantly, and drastically with the same scoring system. Question 8 had the options of: never, less than once a month, at least once a month, at least once a week, and daily, scored in the same manner. The questions and answer options appeared in a table with instructions to circle the answer that they believed serves as the most accurate response based on their experiences.

To answer research questions 3 and 4, virtually identical sets of options appeared for participants to choose from and rank in order from 1-8, with 1 indicating the best answer to the question and 8 as the worst answer to the question. Subjects were allowed to put NA to indicate that a response choice was deemed as not applicable to their situation. To explore research question 3, subjects asked, were "What has the most impact for changing your belief systems and/or behavior when you encounter Christians sharing their faith through social media?" For answering research question 4, respondents were asked, "What do you like seeing the most when you encounter Christians sharing their faith through social media?" The possible options for participants appears below, with the bracketed section of option 7 appearing in the impact of belief systems and/or behavior section but not for preferences in those options.

Direct quotations from the Bible

Images with Bible verses

Personal stories of how God affected their lives

Sharing thoughts about God to teach/encourage others

Explaining personal beliefs on a particular topic

Posting inspirational quotes about faith

Posting videos about faith [and impacting lives]

Examples of living as a good Christian

The ordinal ranking list provided to answer research question 
5 contained two different options included based on the expert panel's feedback about what offended them when encountering Christian faith sharing posts through social media. In addition, the order was changed slightly to accommodate those insertions and two corresponding deletions. The list of options for what offended social media users when encountering Christian faith sharing through that medium appears below, with subjects asked to provide the same 1-8 ranking scale to the left of each option.

Personal stories of how God affected their lives

Sharing thoughts about God to teach/encourage others

Explaining personal beliefs on a particular topic

Posting inspirational quotes about faith

Posting videos about faith and impacting lives

Chain messages (ex. Send this to 10 people to receive a blessing.)

Likes or Retweets (ex. Like/retweet if you're thankful for God today.)

Examples of living as a good Christian

The survey also included demographic questions for items such as age, gender, ethnicity, as well as a question asking them to rate their relationship with God. All participants voluntarily took the survey through convenience sampling and were offered compensation through a piece of candy following their study participation. Subjects' names were not collected on the surveys or recorded in any other manner to assure their privacy and confidentiality in the research.

\section{Results}

Seventy-nine people participated in the research and demographic data was reported on the surveys for all but two subjects. Considering those who reported their race and ethnicity, the study contained at least 49 White, 17 Hispanic, 5 Black, 4 mixed race participants, 1 Asian, and 1 who reported themselves as other. An additional subject chose to leave the gender category blank, so 50 subjects indicated their gender as female and 26 as male. The survey provided options for ages given in age ranges to provide greater anonymity at a smaller college with approximately 500 students and 100 faculty and staff members. Therefore, the age breakdown included 68 subjects less than 30 years old, 4 subjects from 30-39 years old, 3 subjects from 40-49 years old, 1 subject from 50-59 years old, and 1 subject at least 60 years old.

Regarding other survey questions, some subjects left at least one entry blank by completing part of a section or abstaining from a section entirely. While NA (not applicable) was given as an option in the ordinal ranking, a few subjects left options blank instead. When a missing data point seemed obvious based on other responses in that section, that data point was added. When subjects' missing answers could not be easily discerned, that subject's data was removed from data analysis for that particular section. Based on this method of data inclusion, 79 subjects' data were used for the effects on Christian faith sharing through social media on belief systems and behavior, 71 subjects had data included for types of Christian faith-sharing posts affecting belief systems and/or behavior as well as the most liked types of posts, and 65 subjects' data were included for the most offensive types of Christian faith sharing posts through social media.

Questions 1-8 received the following mean scores in numerical order: $2.59,2.48,1.99,2.60,2.34,2.29,2.15$, and 4.13. Therefore, for Questions 1, 2, 4, and 5, participants scored approximately halfway between "rarely" and "sometimes" for the effect of Christian faith sharing through social media on their belief systems and behavior. In Questions 3, participants averaged "rarely" on feeling pressure to change their belief systems or behavior from online faith sharing. From Questions 6 and 7, subjects scored just over "slightly" for the effects on their belief systems and behavior. Finally, Question 8 responses showed that subjects encountered Christian faith sharing through social media on average at least once a week, with some respondents experiencing daily encounters. A table appears below to illustrate the findings for this section of the survey.

Table 1: Effects of Christian Faith Sharing Through Social Media on Belief Systems and Behavior

\begin{tabular}{|c|c|}
\hline Survey Question & $\begin{array}{l}\text { Average Score (Range in } \\
\text { Likert-Type Scale) }\end{array}$ \\
\hline $\begin{array}{l}\text { 1. When you encounter } \\
\text { Christians sharing their faith } \\
\text { through social media, how } \\
\text { often has it affected your belief } \\
\text { systems concerning anything } \\
\text { connected to your faith? }\end{array}$ & $\begin{array}{l}2.59 \text { (Between "Rarely" and } \\
\text { "Sometimes") }\end{array}$ \\
\hline $\begin{array}{l}\text { 2. When you encounter } \\
\text { Christians sharing their faith } \\
\text { through social media, how } \\
\text { often has it affected your belief } \\
\text { systems in any other areas? }\end{array}$ & $\begin{array}{l}2.48 \text { (Between "Rarely" and } \\
\text { "Sometimes") }\end{array}$ \\
\hline $\begin{array}{l}\text { 3. When you encounter } \\
\text { Christians sharing their faith } \\
\text { through social media, how often } \\
\text { have you felt pressure to change } \\
\text { your beliefs and/or actions? }\end{array}$ & 1.99 (Just Under “Rarely”) \\
\hline $\begin{array}{l}\text { 4. After encountering Christians } \\
\text { sharing their faith through social } \\
\text { media, how often has it affected } \\
\text { your behavior concerning } \\
\text { anything connected to your faith? }\end{array}$ & $\begin{array}{l}2.60 \text { (Between "Rarely" and } \\
\text { "Sometimes") }\end{array}$ \\
\hline $\begin{array}{l}\text { 5. After encountering Christians } \\
\text { sharing their faith through social } \\
\text { media, how often has it affected } \\
\text { your behavior in any other areas? }\end{array}$ & $\begin{array}{l}2.34 \text { (Between "Rarely" and } \\
\text { "Sometimes") }\end{array}$ \\
\hline
\end{tabular}


6. To what degree would you estimate that encountering Christians sharing their faith through social media has affected your belief systems?

7. To what degree would you estimate that encountering Christians sharing their faith 2.15 (Just Above "Slightly") through social media has affected your behavior?

8. How frequently do you encounter Christians sharing their faith through social media?

4.13 (Just Above "At Least Once a Week")

To determine correlations between these questions, Pearson's r-squared tests were conducted. The correlations between questions in the same research question category (changes in belief systems and changes in behavior) are all highly significant, which makes logical sense based on the overlapping topics. However, contrary to the researchers' second hypothesis, the correlations between belief system changes and behavior changes are almost as high. This relates well to Bandura's (1971) social learning theory, showing that the environmental Christian faith sharing through social media affected their belief systems and behaviors far more than societal pressures to behave in the same manner. Therefore, the data supports $\mathrm{H} 1$ but does not support H2. Both null hypotheses should be rejected for the first two research questions because of the data in Table 1 as well as the significant effect sizes from the Pearson's $r$ correlations. The results of that analysis appear in Table 2, with moderate effect sizes highlighted in green, all of which have a value of $\mathrm{p}<.001$. Questions regarding belief system changes are highlighted in red and questions regarding behavior changes are highlighted in orange. As noted below, the frequency of social media use (Q8) had a moderate positive correlation with one question regarding belief system change and one question regarding behavior change.

Table 2. Pearson $r$ Values of Belief System Changes, Behavior Changes, and Other Correlations

\begin{tabular}{|c|c|c|c|c|c|c|c|c|}
\hline Question & Q1 & Q2 & Q3 & Q4 & Q5 & Q6 & Q7 & Q8 \\
\hline Q1 & 1.00 & & & & & & & \\
\hline Q2 & 0.54 & 1.00 & & & & & & \\
\hline Q3 & 0.31 & 0.39 & 1.00 & & & & & \\
\hline Q4 & 0.56 & 0.62 & 0.49 & 1.00 & & & & \\
\hline Q5 & 0.51 & 0.46 & 0.49 & 0.60 & 1.00 & & & \\
\hline Q6 & 0.65 & 0.57 & 0.31 & 0.52 & 0.53 & 1.00 & & \\
\hline Q7 & 0.52 & 0.54 & 0.48 & 0.67 & 0.54 & 0.67 & 1.00 & \\
\hline Q8 & 0.31 & $\mathbf{0 . 1 9}$ & $\mathbf{0 . 1 8}$ & $\mathbf{0 . 1 3}$ & $\mathbf{0 . 0 8}$ & $\mathbf{0 . 1 7}$ & 0.31 & 1.00 \\
\hline
\end{tabular}

An ANOVA supported the researchers' hypothesis for research question 3, which asked, "Do diverse methods of Christian faith sharing through social media differentially impact social media users' belief systems and/or behavior?" This finding reflected significant difference patterns overall in the scores of those options, $F(7,560)=21.62, p<.001$. The mean scores for the eight categories are as follows (in the same order as the list above and from the survey): 4.83, 5.91, 2.48, 3.69, 4.76, 5.72, 4.96, and 3.85. Conducting paired t-tests shows a significant difference between the most influential method of Christian faith sharing through social media (personal stories of how God affected their lives) and the second strongest category, $\mathrm{t}(140)=3.89, p<.001$. The second and third ranked options based on effect magnitude (sharing thoughts about God to teach/encourage others and examples of living as a good Christian) did not have a significant difference between them, but had a significant difference between them and the fourth most influential option $(p<.05)$. The fourth through sixth most influential options based on effect size (explaining personal beliefs on a particular topic, direct quotations from the Bible, and posting videos about faith and impacting lives) all did not have significant differences between them but had a significantly greater effect ( $p$ $<.05$ ) than the last two options (posting inspirational quotes about faith and images with Bible verses). The options appear in Table 3 in order of most influential effects to least influential as ranked by the participants.

Table 3. Reported Order of Effects on Belief Systems and/or Behavior

\begin{tabular}{|c|c|c|}
\hline Rank & $\begin{array}{c}\text { Category of } \\
\text { Social Media Post }\end{array}$ & $\begin{array}{l}\text { Average } \\
\text { Score }\end{array}$ \\
\hline 1 & $\begin{array}{l}\text { Personal stories of how God affected their } \\
\text { lives }\end{array}$ & 2.48 \\
\hline 2 & $\begin{array}{l}\text { Sharing thoughts about God to teach/ } \\
\text { encourage others }\end{array}$ & 3.49 \\
\hline 3 & Examples of living as a good Christian & 3.65 \\
\hline 4 & $\begin{array}{l}\text { Explaining personal beliefs on a particular } \\
\text { topic }\end{array}$ & 4.76 \\
\hline 5 & Direct quotations from the Bible & 4.83 \\
\hline 6 & $\begin{array}{l}\text { Posting videos about faith and impacting } \\
\text { lives }\end{array}$ & 4.96 \\
\hline 7 & Posting inspirational quotes about faith & 5.72 \\
\hline 8 & Images with Bible verses & 5.91 \\
\hline
\end{tabular}

The data also supported the alternative hypothesis in answering research question 4, which asked, "Do social media users prefer certain methods of Christian faith sharing through social media over others?" In responding to the rank options provided to this question, users prefer provided the same rank order of responses as research question 3. The average scores shown in order from the list provided is: $5.10,5.43,2.76,3.82,4.70,5.15,5.11$, and 3.97. Also, the results of the ANOVA showed a highly significant pattern that emerged from users' preferred methods, $F(7,560)=$ $13.06, p<.001$. However, the grouping of the categories changed 
somewhat in terms of their statistically significant differences from one another as determined by paired $t$-tests. Conducting $t$-tests between each pair showed a similar difference between the most preferred method of Christian faith sharing through social media (personal stories of how God affected their lives) and all other options, $t(140)=3.38, p<.001$. The next two options by effect ranking (sharing thoughts about God to teach/encourage others and examples of living as a good Christian) did not have a significant difference between them and only sharing thoughts about God had a significant difference between it and the fourth most preferred option $(p<.05)$. The fourth through seventh options have no significant differences between each other based on preference, with included: explaining beliefs about a topic, direct quotations from the Bible, posting videos about faith, and posting inspirational quotes about faith respectively. However, they all had a significantly stronger score $(p<.05)$ than the least preferred option (images with Bible verses).

Table 4. Reported Order of Preference for Social Media Users to Encounter

\begin{tabular}{|c|l|c|}
\hline Rank & \multicolumn{1}{|c|}{ Category of Social Media Post } & $\begin{array}{c}\text { Average } \\
\text { Score }\end{array}$ \\
\hline 1 & $\begin{array}{l}\text { Personal stories of how God affected their } \\
\text { lives }\end{array}$ & 2.76 \\
\hline 2 & $\begin{array}{l}\text { Sharing thoughts about God to teach/ } \\
\text { encourage others }\end{array}$ & 3.82 \\
\hline 3 & Examples of living as a good Christian & 3.97 \\
\hline 4 & $\begin{array}{l}\text { Explaining personal beliefs on a } \\
\text { particular topic }\end{array}$ & 4.70 \\
\hline 5 & Direct quotations from the Bible & 5.10 \\
\hline 6 & $\begin{array}{l}\text { Posting videos about faith and impacting } \\
\text { lives }\end{array}$ & 5.11 \\
\hline 7 & Posting inspirational quotes about faith & 5.15 \\
\hline 8 & Images with Bible verses & 5.43 \\
\hline
\end{tabular}

Finally, the survey provided data to answer research question 5, which asked, "Do social media users take more offense from certain methods of Christian faith sharing through social media over others?" The average scores for the offensiveness of posts in the order listed in the methods section and survey were: 5.97, 5.43, $4.45,4.88,4.85,2.40,3.03$, and 5.62. An ANOVA indicated that the pattern of differences in means between the categories have a significant effect size, $F(7,512)=24.69, p<.001$, supporting the alternative hypothesis chosen for this research question. Chain messages and messages requesting likes or retweets did not have a statistically significant difference compared to one another, but they have a highly significant difference in means compared to all of the other posts listed according to paired $t$-tests. For example, comparing the second to third post offensive types of posts gave the following results: $t(125)=3.46, p<.001$. The third most offensive type of post (explaining personal beliefs on a particular topic) did not have a significant difference from the fourth and fifth ranked posts (posting inspirational quotes about faith and posting videos about faith and impacting lives), but had a significant difference compared to the other less offensive posts ( $p$ $<.005)$. The fourth and fifth ranked posts do not have a significant difference between each other or the sixth ranked post, but they do compared the two least offensive posts $(p<.05)$. The three least offensive posts (personal stories of how God affected their lives, examples of living as a good Christian, and sharing thoughts about God to teach/encourage others) had no significant differences between one another. The overall ranking of these posts from most offensive to least offensive appears below.

Table 5. Reported Order of Most Offensive to Least Offensive Posts

\begin{tabular}{|c|c|c|}
\hline Rank & $\begin{array}{c}\text { Category of Social } \\
\text { Media Post }\end{array}$ & Average Score \\
\hline 1 & $\begin{array}{l}\text { Chain messages } \\
\text { (ex. Send this to } 10 \\
\text { people to receive a } \\
\text { blessing.) }\end{array}$ & 2.40 \\
\hline 2 & $\begin{array}{l}\text { Likes or Retweets } \\
\text { (ex. Like/retweet if } \\
\text { you're thankful for } \\
\text { God today.) }\end{array}$ & 3.03 \\
\hline 3 & $\begin{array}{l}\text { Explaining } \\
\text { personal beliefs on } \\
\text { a particular topic }\end{array}$ & 4.45 \\
\hline 4 & $\begin{array}{l}\text { Posting } \\
\text { inspirational quotes } \\
\text { about faith }\end{array}$ & 4.85 \\
\hline 5 & $\begin{array}{l}\text { Posting videos } \\
\text { about faith and } \\
\text { impacting lives }\end{array}$ & 4.88 \\
\hline 6 & $\begin{array}{l}\text { Personal stories of } \\
\text { how God affected } \\
\text { their lives }\end{array}$ & 5.43 \\
\hline 7 & $\begin{array}{l}\text { Examples of living } \\
\text { as a good Christian }\end{array}$ & 5.62 \\
\hline 8 & $\begin{array}{l}\text { Sharing thoughts } \\
\text { about God to teach/ } \\
\text { encourage others }\end{array}$ & 5.97 \\
\hline
\end{tabular}

In a qualitative research project by Bowman (2020), college students at the same institution typically described the 4th-8th ranked posts on this offensiveness scale as encouraging in a qualitative study describing a similar topic. Therefore, while subjects needed to report these categories as offensive based on the quantitative nature of the section, many participants in the other research depicted those last five categories as more positive than negative in nature. In addition, the students in that same study (Bowman, 2020) repeatedly reported the three most offensive posts as offensive without any direct prompting towards negatively evaluating those types of posts. 


\section{Conclusion}

Clearly, Christian faith sharing through social media exerts an impact on its recipients and the manner in which faith sharing occurs makes a difference in terms of users' preferences and perceived impact. This effect occurs not just in belief systems, but also in consequent behavior corresponding to Bandura's (1971) social learning theory. These findings may prove meaningful for Christians who share their faith through social media in multiple regards. First, this research shows that Christians can significantly impact those who encounter their posts, which may prompt them to further their efforts to spread their message to others. However, some faith sharing methods proved much more effective than others, which could cause those faith sharers to examine the results of this research and favor techniques that participants reported as more effective and preferred. In addition, recipients of Christian faith sharing through social media reported certain techniques as more offensive than others, which might cause them to note offensive methods and attempt to avoid those approaches to increase effectiveness and minimize offensiveness. This could help reduce the number and severity of conflicts between Christians and those who receive their message if they apply these findings in an astute manner.

In considering these findings and conclusions, it should be noted that the majority of respondents fell into the age range of college students, so these preferences and effects mostly summarize the belief systems, behaviors, and perceptions of college students and/or young adults. While some respondents at least 30 years old participated, further research could systematically explore the effects of Christian faith sharing through social media among different age groups. Furthermore, this study has the weakness of collecting data at a Christian college, probably resulting in a sample that contained a higher concentration of participants who would readily receive Christian faith sharing through social media. While many of the students do not actively practice the Christian faith, they have at least become accustomed to hearing the Christian message through this institution. Therefore, an option for future research would involve exploring these research questions using more diverse populations or focusing on nonChristians specifically in that research. Finally, the quantitative nature of this research did not allow for subjects to provide answers beyond the options provided, so further research should also take place in the subject area using qualitative measures as noted by Previte (2017). From this research and these other future recommendations, the common practice of Christian faith sharing may have a greater impact and less offensiveness for those who encounter their message.

\section{Conflict of Interest/Disclosure of Interest}

The authors declare that there is no conflict of interest.

\section{References}

Audette, A. P., \& Weaver, C. L. (2016). Filling pews and voting booths: The role of politicization in congregational growth. Political Research Quarterly, 69(2), 245-257. doi:10.1177/1065912916634896

Bandura, A. (1963). The role of imitation in personality. The Journal of Nursery Education, 18(3), 1-9. Retrieved from https:// www.uky.edu/ eushe2/Bandura/Bandura1963.pdf

Bandura, A. (1965). Influence of models' reinforcement contingencies on the acquisition of imitative responses. Journal of Personality and Social Psychology, 1(6), 589-595. doi:10.1037/ h0022070

Bandura, A. (1969). Social-learning theory of identificatory processes. In D. A. Goslin (Ed.), Handbook of socialization theory and research (pp. 213-262). Chicago, IL: Rand McNally.

Bandura, A. (1971). Social learning theory. New York, NY: General Learning Press.

Bandura, A., Ross, D., \& Ross, S. (1963). Imitation of filmmediated aggressive models. Journal of Abnormal and Social Psychology, 66(1), 3-11. doi:10.1037/h0048687

Bosch, M. D., Sanz, J. L. M., Abello, J. M. C., Torrents, J. S., \& Gauxachs, A. S. (2017). Open wall churches. Catholic construction of online communities. Prisma social: Revista de cienciassociales, 12(1), 298-323. Retrieved from https://dialnet.unirioja.es/servlet/ articulo? codigo $=6234753$

Bowman, G. A. (2020). The infuence of Christian faith sharing through social media on college students (Order No. 28255655) [Doctoral dissertation, Grand Canyon University]. ProQuest Dissertations and Theses Global. https://pqdtopen.proquest.com/doc/2469099108.html?FMT=ABS

Bowman, G. A. (2019). Best practices for building social networking sites and attracting members. Journal of Digital and Social Media Marketing, 7(3), 281-287. doi:10.6084/m9.figshare.11473728

Brubaker, P. J., \& Haigh, M. M. (2017). The religious Facebook experience: Uses and gratifications of faith-based content. Social Media + Society, 3(2), 1-11. doi:10.1177/2056305117703723

Chen, M.-F., Wang, R.-H., \& Hung, S.-L. (2015). Predicting health-promoting self-care behaviors in people with pre-diabetes by applying Bandura social learning theory. Applied Nursing Research, 28(4), 299-304. doi:10.1016/j.apnr.2015.01.001

Deaton, S. (2015). Social learning theory in the age of social media: Implications for educational practitioners. Journal of Educational Technology, 12(1), 1-6. Retrieved from https://files. eric.ed.gov/fulltext/EJ1098574.pdf 
Diprose, R. (2018). Inequalities and indirect conflict interventions: The evidence on perceptions of difference, social cohesion, and sub-national variations in violence in central Sulawesi, Indonesia.

Journal of Indonesian Social Sciences and Humanities, 8(2), 95147. doi:10.14203/jissh.v2i0.22

Efiong, J. E. (2015). Theology and information technology. Methodist Journal of Theology, 2(1), 160-179. Retrieved from http://mtisagamu.org/journals/Theology\%20and $\% 20$ Information $\% 20$ Technology.pdf

Kelly, C. M. (2015). Depth in an age of digital distraction: The value of a Catholic college in today's world. Journal of Catholic Higher Education, 34(2), 113-133. Retrieved from: http://www1. villanova.edu/content/dam/villanova/mission/mandm_assets/ Newsletter/1795.pdf

Knafo, H. (2016). The development of body image in school-aged girls: A review of the literature from sociocultural, social learning theory, psychoanalytic, and attachment theory perspectives. The New School Psychology Bulletin, 13(2), 1-16. Retrieved from http://www.nspb.net/index.php/nspb/article/view/270

Lee, C. T., \& Hsieh, S. (2016). The effects of social capital on brand evangelism in online brand fan page: The role of passionate brand love. Pacific Asia Conference on Information Systems, Chiayi, Taiwan, Summer 2016. Pacific Asia Journal of the Association for Information Systems.

Lehtipuu, O. (2016). "What harm is there for you to say Caesar is Lord?" Emperors and the imperial cult in early Christian stories of martyrdom. Collegium, 20(1), 96-118. Retrieved from https:/helda.helsinki.fi/bitstream/handle/10138/161318/07_ Lehtipuu2104.pdf? sequence $=1$

Lie, S. (2017). How best to evangelize to nonbelievers: Cultural persuasion in American and Chinese Indonesian evangelical Christian discourse on relational evangelism. Journal of

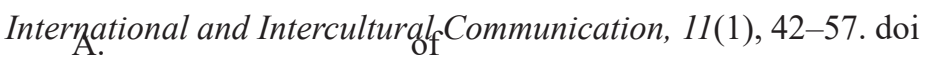
:10.1080/17513057.2017.1349920

Lim, (2017). Effectiveways using socialmedia:Aninvestigation of Christian churches in South Australia. Christian Education Journal, 14(1), 23-41. Retrieved from https://search-proquestcom.lopes.idm.oclc.org/pqdtglobal/docview/1891739304/ fulltext/85F14A085F2F4260PQ/1 ?accountid=7374
Mayhew, M. J., Rockenbach, A. N., Bowman, N. A., Lo, M. A., Starcke, M. A., Riggers-Piehl, T., \& Crandall, R. E. (2017). Expanding perspectives on evangelicalism: How non-evangelical students appreciate evangelical Christianity. Review of Religious Research, 59(2), 207-230. doi:10.1007/s13644-017-0283-8

O’Brien, T. L., \& Noy, S. (2015). Traditional, modern, and post-secular perspectives on science and religion in the United States. American Sociological Review, 80(1), 92-115. doi:10.1177/0003122414558919

Philips, J. (2015). The crusades: A complete history. History Today, 65(5), 26-34. Retrieved from:

http://xs6th8dt4r.scholar.serialssolutions.

Previte, R. C. (2017). Christian adolescents and social media: Sharing their faith online (Doctoral dissertation).Retrieved from Proquest Dissertations Publishing. (10276173).

Simmons, A. J. (2015). Rescuing the millennials; Four essential lessons learned and eight key principles to reclaiming this generation (Doctoral thesis). Retrieved from Digital Commons @ Liberty University. (1066)

Van der Walt, B. J. (2017). Sharing an integral Christian worldview with a younger generation: Why and how should it be done and received? In Die Skriflig/In Luce Verbi, 51(1), 1-11. doi:10.4102/ ids.v51i1.2245

Vidyakala, K., \& Nithyakala, K. (2016). An analysis of usage of social networking sites among college students. International Journal of Informative \& Futuristic Research, 4(2), 53735377. Retrieved from http:// www.ijifr.com/pdfsave/02-112016702IJIFR-V4-E2-067.pdf

Voas, D., \& Chaves, M. (2016). Is the United States a counterexample to the secularization thesis? American Journal of Sociology, 121(5), 1517-1556. doi:10.1086/684202

White, P., Tella, F., \& Ampofo, M. D. (2016). A missional study of the use of social media (Facebook) by some Ghanaian Pentecostal pastors. Koers - Bulletin for Christian Scholarship, 81(2), 1-8. doi:10.19108/koers.81.2.2250

Citation: Glen Alan Bowman, Blessing Osueke and Samantha Baires "Effects of Christian Faith Sharing Through Social Media: Examining Belief System Changes, Behavioral Changes, and User Preferences”. American Research Journal of Humanities and Social Sciences, Vol 7, no. 1, 2021, pp. 1-8.

Copyright (c) 2021 Glen Alan Bowman et al., This is an open access article distributed under the Creative Commons Attribution License, which permits unrestricted use, distribution, and reproduction in any medium, provided the original work is properly cited. 